\title{
Fibroleomyosarcoma of Vagina in a Bitch
}

\author{
P. Veena, P. Sankar, R. V. Suresh Kumar, N. Dhana Lakshmi and S. Kokila \\ Department of Veterinary Surgery and Radiology \\ College of Veterinary Science, \\ Sri Venkateswara Veterinary University, Tirupati-517502 (A.P), India. \\ * Corresponding author email: sansurvet@gmail.com
}

\section{Case History and Observation}

A 6 year old Spitz dog was referred to the Department of Veterinary Surgery and Radiology, College of Veterinary Science, Tirupati with a history of distended abdomen mass popping out off the vulva since three months, not defecated and urinated since a day. On physical examination the animal was active, had a normal physical parameters. Genital tract examination revealed a growth (Fig.1) with a stock like structure originating from the vaginal mucous membrane. Radiography of the lateral thorax and abdomen did not reveal any secondary lesions either in the lung or other abdominal organs but revealed fecal filled dilated colon and distended bladder. No major abnormalities were detected from the hematological examination.

\section{Treatment and Discussion}

The dog was premedicated with atropine sulphate @ $0.04 \mathrm{mg} / \mathrm{kg}$ body weight subcutaneously and sedated with xylazine hydrochloride $1.0 \mathrm{mg} / \mathrm{kg}$ body weight intramuscularly. General anaesthesia was using ketamine hydrochloride @ $5.0 \mathrm{mg} / \mathrm{kg}$ body weight and diazepam $0.3 \mathrm{mg} / \mathrm{kg}$ body weight intravenously. An episiotomy incision of $3 \mathrm{~cm}$ was made starting from the dorsal commissure of the vulva toward the anal opening and the growth was resected (Fig.2) out. The episiotomy incision was closed by using 2/0 chromic catgut with simple interrupted suture pattern. Skin incision was closed routinely. Animal was given antibiotic and anti inflammatory therapy for 5 days. Animal made an uneventful recovery.

Histopatological examination of the tumor showed admixture of smooth muscle, collagen and fobroblastic cells with the presence of mitotic figures (Fig.3). The cells showed anaplastic changes, with thicker chromatin. Different size of cells and shapes of cells were observed. Benign smooth muscle tumor of the vagina and vulva is reported in aged dogs by Thatcher and Bradley, (1983). Clinical signs like vulva discharges and sudden appearance of protruding mass were also observed in this case as observed by Thatcher and Bradley (loc cit). Colonic and urinary obstruction due to dilated colon and distended bladder respectively were observed in this case as mentioned by Cooper and Valentine, (2002). Pedunculated thin stalk may be characteristic feature of benign tumor

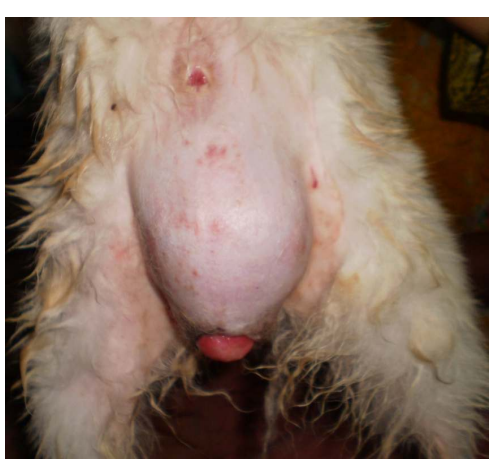

Figure.1: Fibroleomyosarcoma of Vagina

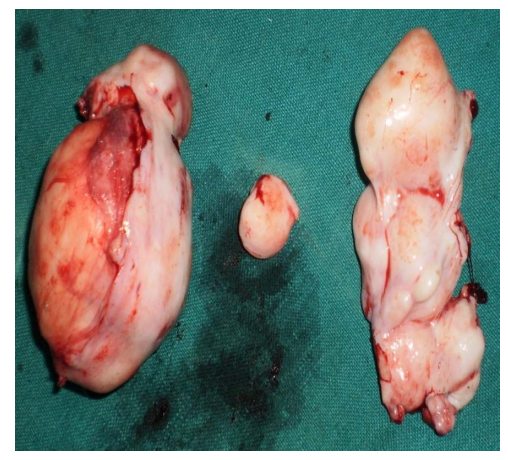

Figure.2: Excised tumorous growth

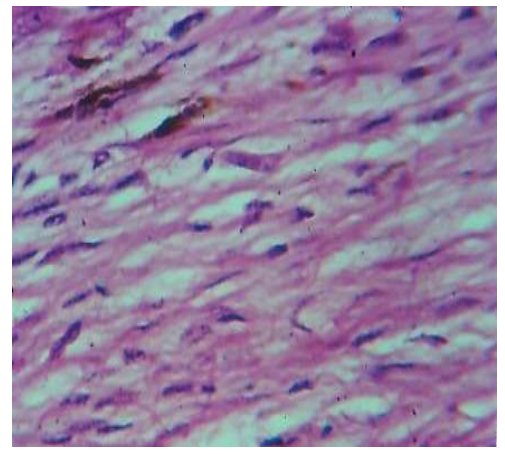

Fig. 3: Photomicrograph showing admixture of smooth muscle, collagen and fibroblastic cells with the presence of mitotic figures $H \& E \times 70$ 
(Brodey and Roszel, 1967), but the attachment of the growth to the vaginal fold resulted in the appearance of a stalk like structure in this case. Increased level of ALT was consistent in cases of fibroleomyosarcoma having hepatocellular damage due to hepatic metastasis (Mesick et al., 2001) however the reason for ALT increases in this dog without any metastases is not known.

\section{References}

1. Brodey, R.S. and Roszel,J.F (1967).Neoplasms of the canine uterus, vagina and vulva. A clinicopathologic survey of 90 cases Journal of American Veterinary Medical Asso.151: 1294-1307.

2. Morrison, W.B. (2002). Cancers of the reproductive tract. In: Cancer in dogs and cats: Medical and Surgical management. $2^{\text {nd }}$ edn W.B Saunders Company, Philadelphia.pp555-564.

3. Thatcher,C and Bradley,R.L (1983). J.Am.Vet.Med.Asso. 183:690.

4. Cooper, B.J and Valentine,B.A (2002). Tumors of Muscle in Meuten D.J. Tumors in domestic Animals IV edition, lowa state press, ABlackwell Publishing Company, lowa.pp319-364.

5. Mesick, J., Haddad,T., Kitchell,B., Caplan,E. and Wallig, M.(2001). Clinical pathology 30:25-27. 